\title{
Human Mobility Control and Labour Market of Migrants in Sicily the Case Study of the Cara of Mineo
}

\author{
Antonella Elisa Castronovo \\ Department of Political Sciences, University of Pisa, Pisa, Italy \\ Email: antoeli@hotmail.it
}

Received 4 January 2015; accepted 22 February 2015; published 28 February 2015

Copyright (C) 2015 by author and Scientific Research Publishing Inc.

This work is licensed under the Creative Commons Attribution International License (CC BY).

http://creativecommons.org/licenses/by/4.0/

cc) (i)

\begin{abstract}
This paper analyses human mobility control in Sicily, linking it with immigrants' employment segregation. The focus is on the Cara of Mineo that, since 2011, has represented one of the most important "laboratory" in order to observe the effects of Italian migration governance. The study is supported by several interviews to stakeholders and to migrant farm hands. The first aim is to show how a place designed to contain the mobility of people [1] can be seen as area where the migration movements are intersected with the economic needs of local context.
\end{abstract}

\section{Keywords}

Sicily, Migration, Human Mobility Control, Labour Exploitation

\section{Introduction}

In this paper, I want to analyse human mobility control in Sicily, linking it with immigrants' employment segregation. My focus is on the Cara of Mineo that, since 2011, has represented one of the most important "laboratory" in order to observe the effects of Italian migration governance.

My analysis is supported by thirty interviews to several stakeholders, such as: union organizers, journalists, intercultural mediator, priest, political and institutional actors, social workers, organization exponents, lawyers, jurist, managers of Cara of Mineo, agronomist, Sicilian and migrant farm hands.

The first aim of this study is to show how a place designed to contain the mobility of people [1] can be seen as area the migration movements are intersected with the economic needs of the local context [2].

\section{Human Mobility Control in Sicily}

Despite internalization process of decision-making mechanisms, severe criteria for the human mobility selection 
have been established, in order to strengthen the migration control policies [3] [4]. Next to these images, international studies have highlighted an opposed analysis perspective: the embitterment of migration policies and the lack of legal entry channels for job express the need of States to govern the foreign labour in order to maintain "pervasive and systematic" inequality's conditions of the immigrants [5]. Although they became indispensable for the survival of some productive sectors, in Italy migrants continue to be in a blackmail position that contributes to perpetuate their exploitation and their deskilling [6]-[8]. In the Italian context, immigration is neither the result of the explicit political choices, nor recruiting programs active on the international labour market. On the contrary, since the beginning, the growth dynamics of the foreign population has been largely independent of the attempts, very shy and full of perverse effects, to govern it. The immigrants' employment process has not been following institutionalized paths [9], but it has been entrusted to the availability of migrants to occupy work positions characterized by the four $d$ [10]—dirty, dangerous, demeaning and demanding — and to their ability to penetrate various labour niches formal and informal market. This approach largely unaware towards migration has had a significant impact on the regulatory and institutional side, with the governance that continues to be characterized in terms of emergency. In this wide context, Sicily has had an important position. The island has represented an arriving place of migrants since '70s [11], in particular for who wants to go to Italy and to Europe. As a result of the security approach of migration policies, the Island has become a crucial place where it would be fought—according to a common vision—a decisive challenge to repel the "invasion" coming from Africa [12].

An important part of the migrants included in the national reception system for asylum seekers is in Sicily (Figure 1).

The map shows the distribution of all migrants' shelters in Italy, save for temporary structures for asylum seekers (Cas), that rose up mainly in Sicily last year (Figure 2).

People included in migrants' shelters have been increased in all national contexts since January 2014, with a percentage rise of $254.8 \%$ in 9 months (Figure 3).

The pie chart shows the asylum seekers distribution in all Italian regions (Figure 4). As we can see, the $24.0 \%$ of them is located in Sicily.

Currently, in this region there are 14.081 people, distributed as [13]:

- 5.185 in temporary migrants structures;

- 4.922 asylum seekers' shelters (Cara, CdA, CPSA);

- 3974 asylum seekers live in Sprar (migrants centers that would be used as secondary shelter).

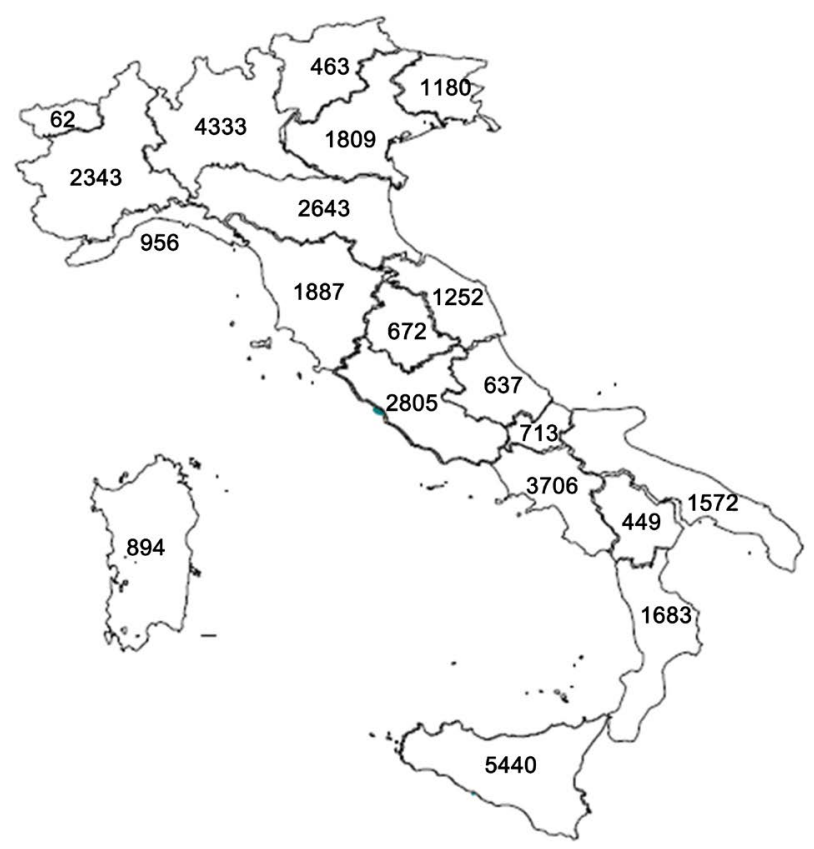

Figure 1. Distribution of migrants included in the Italian reception system. Source: Italy, Ministero dell’Interno 2014 [13]. 


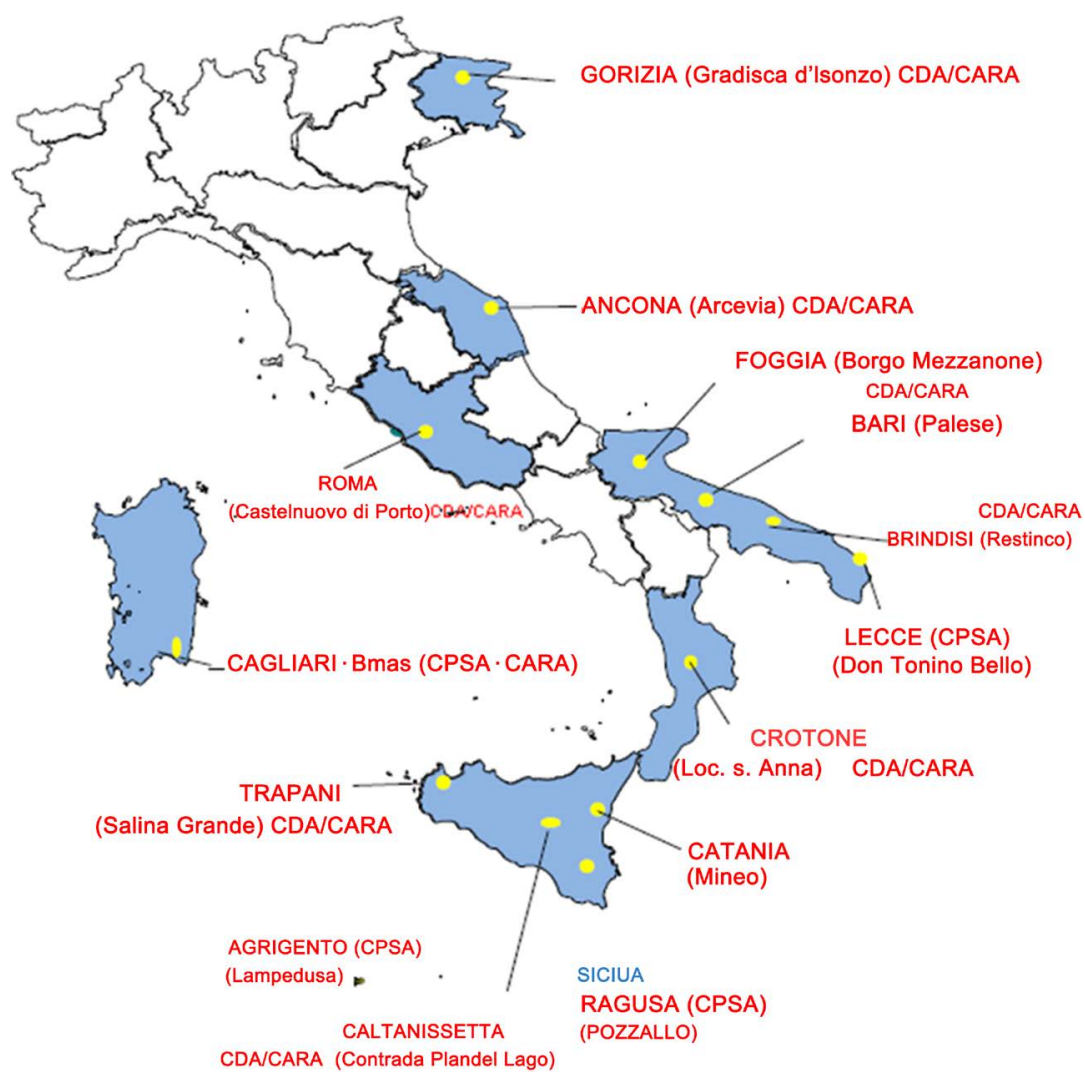

Figure 2. Distribution of migrants' shelters in Italy. Source: Italy, Ministero dell’Interno 2014 [13].

\section{Presenze dei migranti nelle strutture temporanee-CARA-SPRAR} Anno 2014

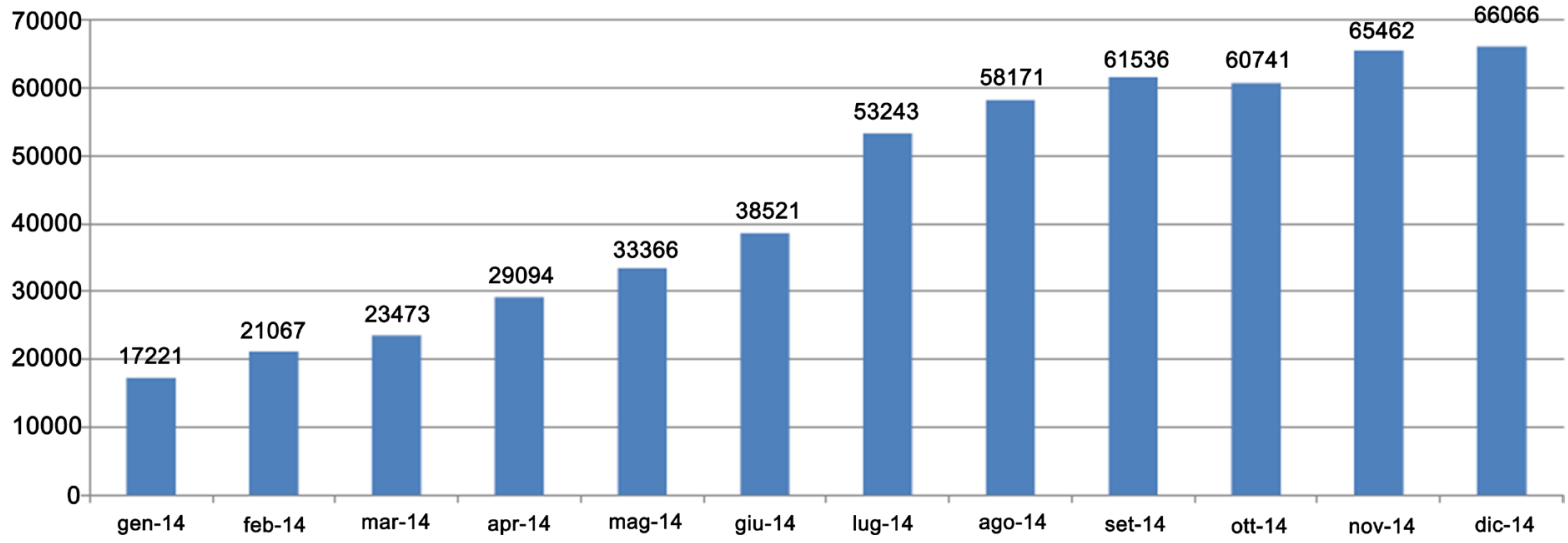

Figure 3. Italian trend of asylum seekers included in migrants' shelters. Source: Italy, Ministero dell'Interno 2014 [13].

These official numbers must be added to the unofficial ones relating to migrants who have decided to not apply for asylum in Italy and who crossed through the Sicilian Island. As it was been documented [14], in 2014, 61,000 of 145,000 refugees landed in Sicily and in Italy were not been registered in Eurodac system.

The critical position of Island in the Mediterranean sea has influenced the labour recruitment process. The presence of immigrants, who often see the region only as temporary stage of a long journey to Italy and Europe, has produced the availability of cheap labour, able to be adapted to temporary needs of the market and local production sectors. 


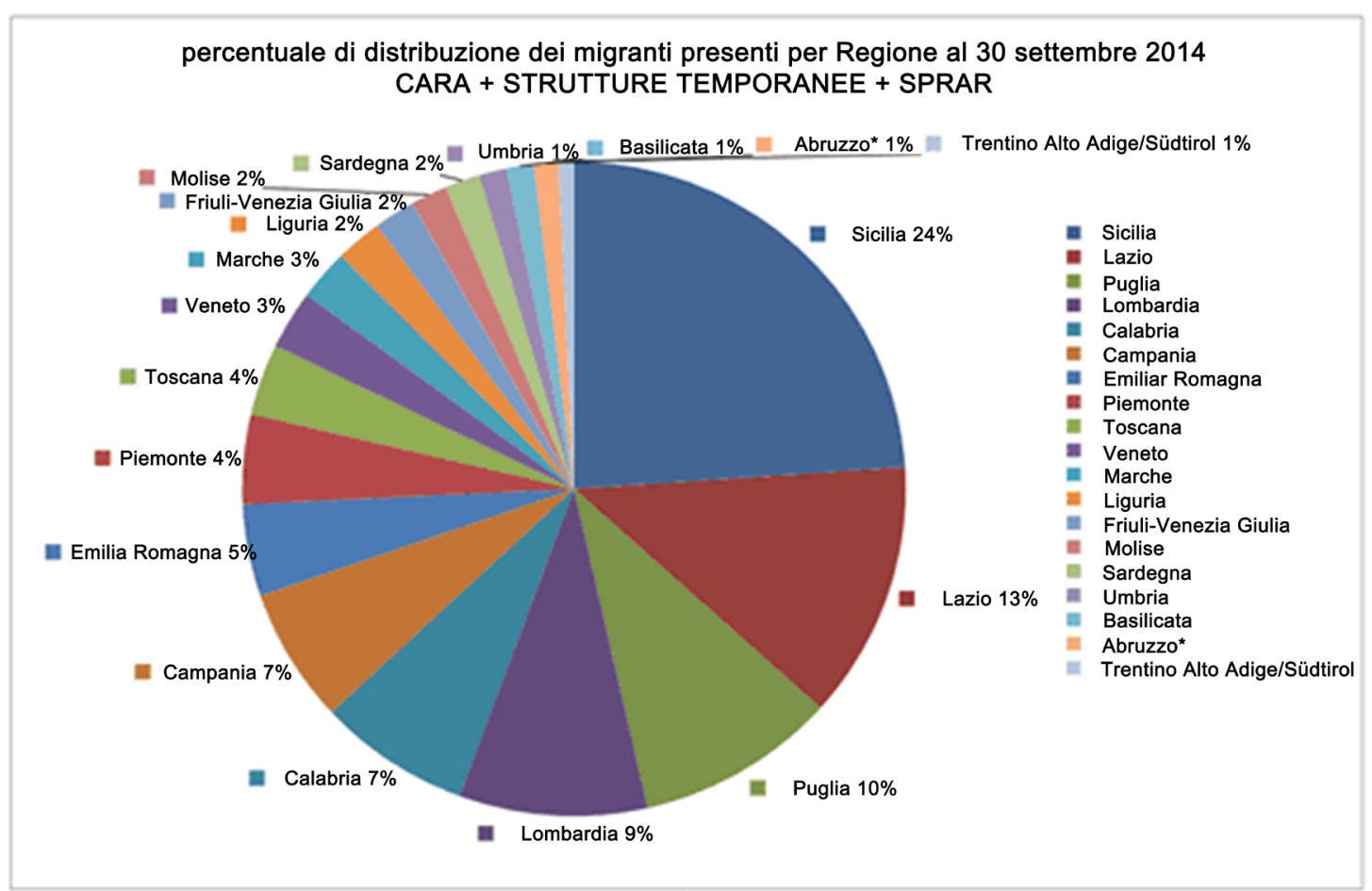

Figure 4. Distribution of asylum seekers in all Italian regions. Source: Italy, Ministero dell’Interno 2014 [13].

The stakeholders I interviewed during my research confirmed this hypothesis: migration process towards Sicily have put in motion a "reception machine" that has acted as device able to select the work force of immigrants. In the matter of this, the deposition of priest of Caltagirone Caritas is emblematic: "Some people landed in Sicily want to go to Europe. Who cannot afford the trip has to work in order to earn money. This people works for the lowest salary, such as 5 or 10 Euros a day".

The presence of people willing to work for very low salary is visible in even more evident forms among the asylum seekers hosted inside the Cara of Mineo.

\section{The Case Study of the Cara of Mineo}

Mineo is a little town that delimits the Calatino area, with other 14 cities: Caltagirone, Castel di Judica, Grammichele, Licodia Eubea, Mazzarrone, Militello Val di Catania, Mineo, Mirabella Imbaccari, Palagonia, Raddusa, Ramacca, San Cono, San Michele di Ganzaria, Scordia e Vizzini (Figure 5).

The Calatino area is characterized by an agricultural economy. Within the district, there is a large variety of cultures: citrus groves, grapevines, olive groves and vegetables.

An important part of work-force is employed in agriculture sector (Table 1): in the Calatino area, the 13.3\% of labour force is represented by farm hands and in some cities this percentage rises to $29.3 \%$ (e.g. Mazzarrone).

The workforce need has attracted immigrants since 90s, with important consequences in the economic and social context. Immigrants from Maghreb were added to communitarian citizens since 2007. As the stakeholders of my research have documented, the arrival of foreign farm hands has produced an ethnic differentiations of wages: North African workers earn less than local workers and Eastern Europe workers still earn less than the North African and the Italian ones.

In 2011 the Cara of Mineo establishment has made the working conditions of migrants in agriculture sector even further worse.

The building was originally a residence for American marines, employed in the military base of Sigonella. The houses with garden inside it reflect an American model of residence (Figure 6).

After American soldiers left it, since 2011 the center has been used to deal with "Nord Africa Emergency" in order to "relieve" Lampedusa island from migrants [12]. 

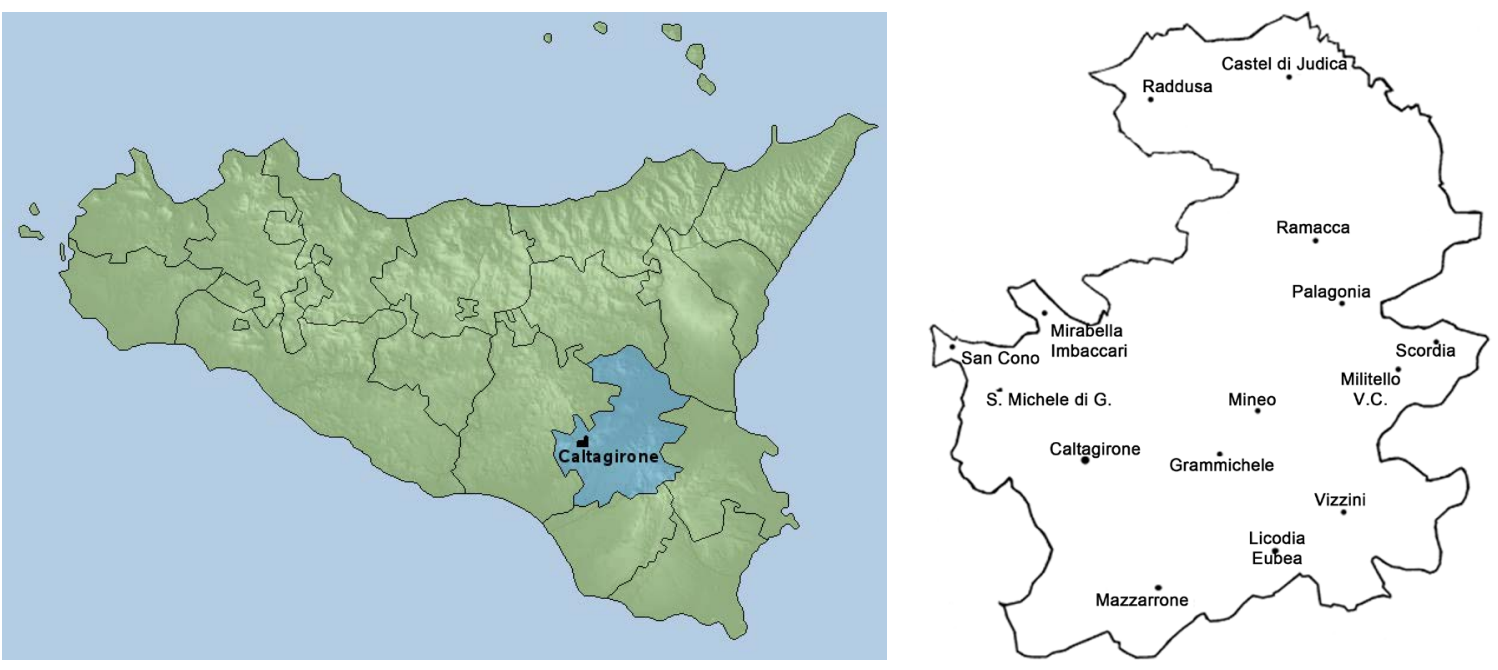

Figure 5. The Calatino area, Sicily.

Table 1. Percentage of agricultural workers on the total working population within the Calatino area.

\begin{tabular}{cccc}
\hline Municipality & Active population & The INPS lists personal & Incidence of agricultural workers (\% value) \\
\hline Caltagirone & 25158 & 1079 & 4.3 \\
Grammichele & 2656 & 720 & 27.1 \\
Licodia Eubea & 1938 & 406 & 20.9 \\
Mazzarrone & 2656 & 777 & 29.3 \\
Militello in Val di Catania & 4971 & 559 & 11.2 \\
Mirabella Imbaccari & 3146 & 202 & 6.4 \\
Palagonia & 11003 & 2946 & 26.8 \\
Ramacca & 7316 & 1129 & 15.4 \\
San Cono & 1731 & 242 & 14.0 \\
San Michele di Ganzaria & 2141 & 195 & 9.1 \\
Scordia & 11616 & 1821 & 15.7 \\
Vizzini & 4091 & 506 & 12.4 \\
Mineo & 3150 & 446 & 14.2 \\
Castel Iudica & 3068 & 387 & 12.6 \\
Raddusa & 2117 & 152 & 7.2 \\
Totale & $\mathbf{8 6 . 7 5 8}$ & $\mathbf{1 1 . 5 6 7}$ & $\mathbf{1 3 . 3}$ \\
\hline
\end{tabular}

Source: Inps data 2013, my elaboration.

At present, the Cara of Mineo is the biggest asylum seekers center in Europe. It is not a closed center: migrants are allowed to go out, but they have to follow opening and closing time.

As the stakeholder documented, there are several difficulties:

1) The center is overcrowded: the structure should host 2000 people, but it contains more of 4000 people;

2) Asylum seekers receive a pocket money of 2.50 Euros a day. This money is not given them in cash, but through various goods, such as cigarettes or phone cards. Many people need to obtain money in cash in order to send it to their countries. This need has been activating illegal forms of these goods' sales inside and outside the center;

3) There is only one Italian school inside the camp and there are not activities able to allow this people to know the social and economic context where they live; 

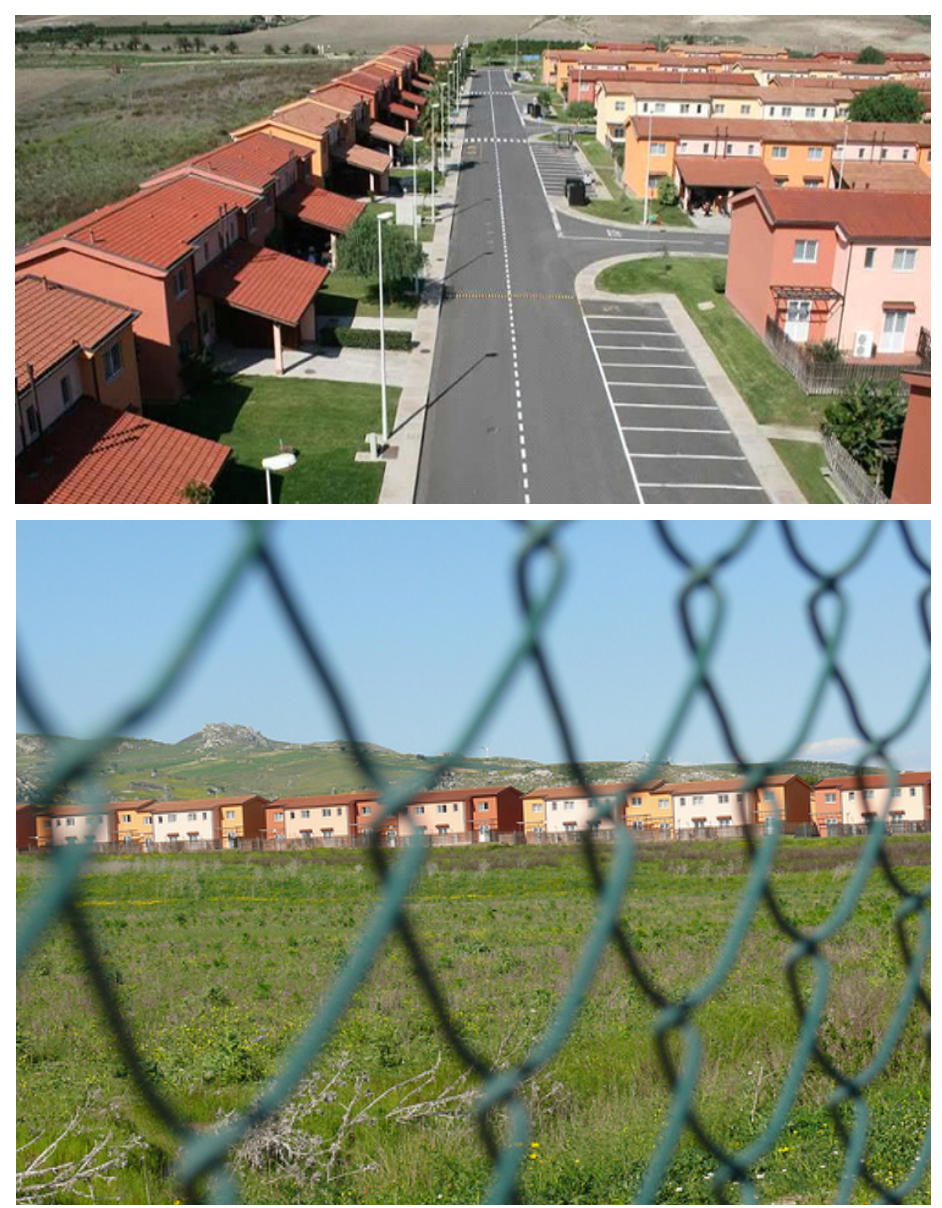

Figure 6. Houses inside the Cara of Mineo. Source: venticinque 2010 [15].

4) the Cara is $11 \mathrm{~km}$ far from the city of Mineo and there is only one bus a day able to transport these people to the near cities.

The geographical position of the Cara of Mineo is crucial to understand the local social dynamics: the building is inside the countryside of Mineo (Figure 7).

This position has been activating an ambiguous tension with the local farmers (Figure 8). On the one hand, the local farmers have organized several protests in order to complain the presence of these people inside their countrysides. On the other hand, the availability of a low cost labour has enticed local farmers into accepting the center.

As the people I interviewed documented, it is consolidating the habit of recruiting people from the Cara of Mineo in order to employ them in the countryside. This practice has been even more useful in a historical phase in which the strong competition with international markets [16] and the prospect of limited profits by harvest season have been pushing the small local producers to leave the fruit on the trees and to pick citruses on a second moment in order to direct them to processing industry.

The economic need of local farmers to bring down the labour cost has been joining with the need of asylum seekers of earning small amounts of money in order to send it to their families back in their origin countries, or to accumulate it to plan their life once obtained the residence document. On the morning, it is possible to observe the many cars and van allocated near the Cara. The asylum seekers and the other people get in these and after they disappear in the farmlands near Mineo, Palagonia and Scordia. The work of these people is both illegal and irregular: asylum seekers housed in the Cara of Mineo have got documents that do not allow them to work. The daily wage is lower than the other foreign workers: these people earn 20, 15 or 10 Euros for 10 hours a day. In the Calatino district, the practice of recruiting people included in migrants' shelters is spreading also among underages, included in specific centers. They are working for a even further lower wage. 


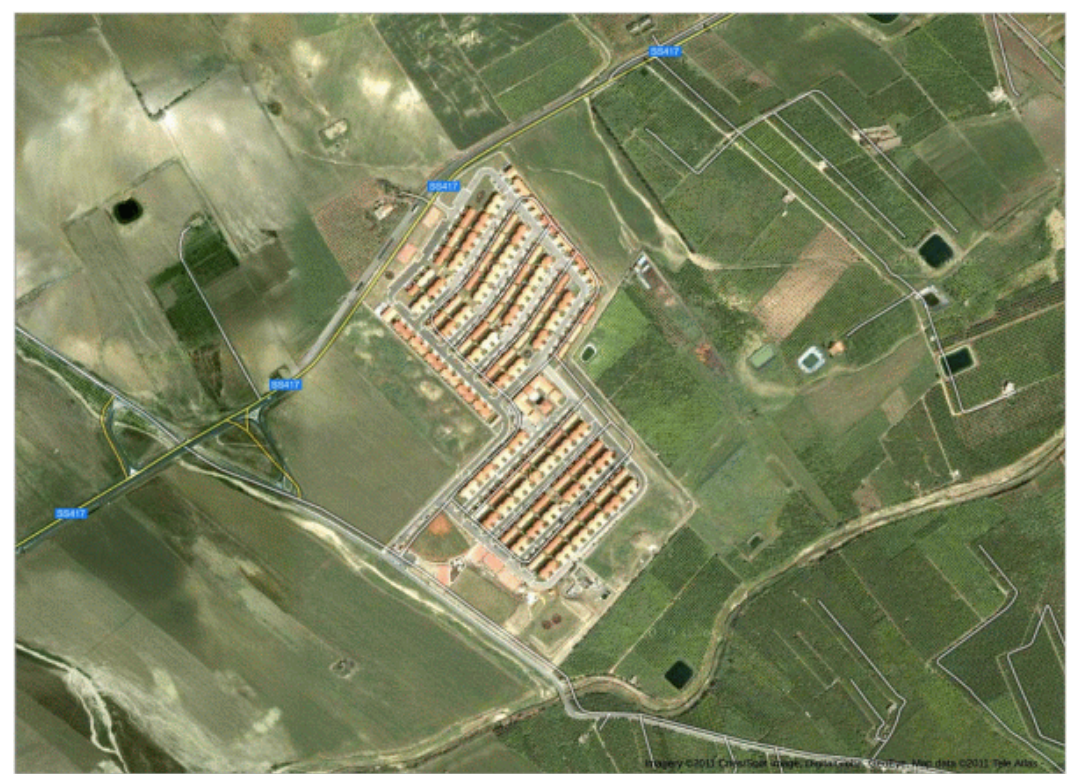

Figure 7. Geographical position of Cara of Mineo.

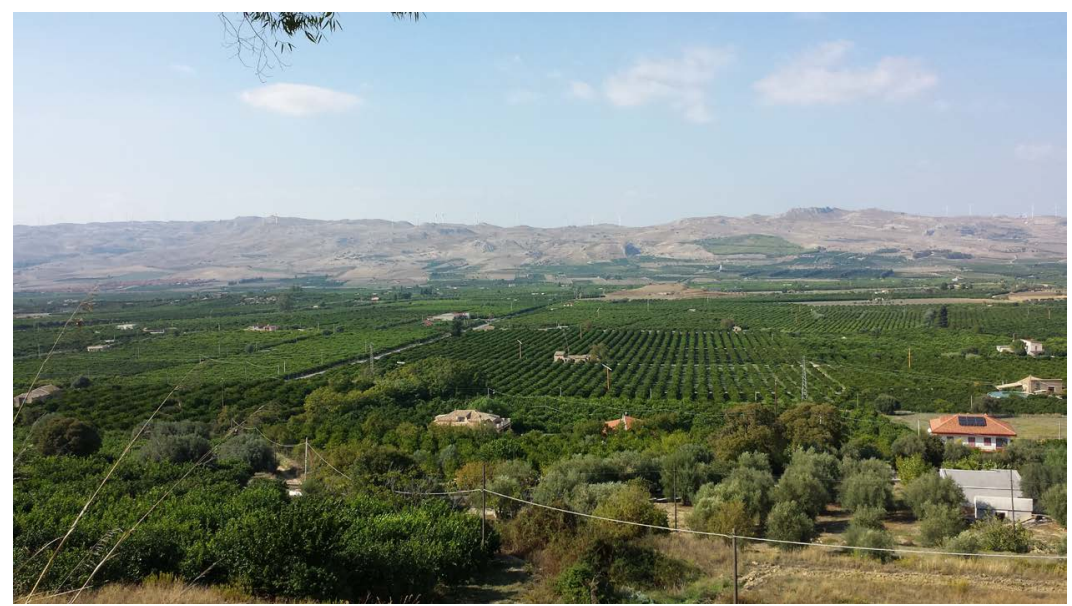

Figure 8. Countryside near the Cara of Mineo.

The situation I presented is able to show us two important aspects of international migration:

1) Migrants allocated in the shelter system are not able to save themselves from the employment segregation process of foreign workers in Sicily: they are the main victims.

2) Asylum seekers' experience allows us to reflect on their ability to resist the restrictions imposed by migration policies.

This situation produces a conflict with the local people and the complicity with the illegal system of labour recruitment in Sicily.

\section{References}

[1] Campesi, G. (2013) La detenzione amministrativa degli stranieri. Storia, diritto, politica. Carocci, Roma.

[2] Gjergji, I. (2006) Espulsione, trattenimento, disciplinamento. Il ruolo dei Cpt nella gestione della forza lavoro. DepDeportate, esuli, profughi. Rivista telematica di studi sulla memoria femminile, 5-6, 97-119.

[3] Dal Lago, A. (1999) Non persone. L’esclusione dei migranti in una società globale. Feltrinelli, Milano.

[4] Mezzadra, S. (2001) Diritto di fuga. Migrazioni, cittadinanza, globalizzazione. Ombre Corte, Verona.

[5] Saraceno, C., Sartor, N. and Sciortino, G. (2013) Stranieri e diseguali. Le disuguaglianze nei diritti e nelle condizioni di 
vita degli immigrati. Il Mulino, Bologna.

[6] Santoro, E. (2010) Diritti umani, lavoro, soggetti migranti: Procedure e forme del “neo-schiavismo”. In: Casadei, T., Ed., Diritti Umani e Soggetti Vulnerabili, Giappichelli, Torino, 227-248.

[7] Perocco, F. (2012) Immigrati e disuguaglianza lavorativa nel sistema delle disuguaglianze italiane. In: Moressa, F.L., Ed., Rapporto Annuale Sull'economia Dell'immigrazione, Immigrati in tempo di crisi. Il Mulino, Bologna, 259-274.

[8] Ambrosini, M. (2013) Immigrazione irregolare e welfare invisibile. Il lavoro di cura attraverso le frontiere. Il Mulino, Bologna.

[9] Zanfrini, L. (2014) Il lavoro. In: Ismu, F., Ed., Ventesimo Rapporto Sulle Migrazioni: 1994-2014. Franco Angeli, Milano, 99-115.

[10] Carens, J. (2008) Live-In Domestics, Seasonal Workers, and Others Hard to Locate on the Map of Democracy. The Journal of Political Philosophy, 16, 419-445. http://dx.doi.org/10.1111/j.1467-9760.2008.00314.x

[11] Cusumano, A. (1976) Il ritorno infelice. I tunisini in Sicilia. Sellerio, Palermo.

[12] Cuttitta, P. (2012) Lo spettacolo del confine. Lampedusa tra produzione e messa in scena della frontiera. Mimesis, Milano.

[13] Ministero dell’Interno (2014) Presenze dei migranti nelle strutture di accoglienza in Italia. http://www.interno.gov.it/it/sala-stampa/dati-e-statistiche/presenze-dei-migranti-nelle-strutture-accoglienza-italia

[14] Redattore sociale (2014) Dei 150 mila migranti sbarcati nel 2014 solo il 30\% ha chiesto asilo politico. http://www.redattoresociale.it/Notiziario/Articolo/470973/Dei-150-mila-migranti-sbarcati-nel-2014-solo-il-30-ha-chies $\underline{\text { to-asilo-politico }}$

[15] Venticinque, L. (2010) (Mineo) Quale futuro per il Residence degli aranci a Cucinella? https://leoneventicinque.wordpress.com/2010/09/23/mineo-quale-futuro-per-il-residence-degli-aranci-a-cucinella-2/

[16] Colloca, C. and Corrado, A. (2013) La globalizzazione delle campagne. Migranti e società rurali nel Sud Italia. Franco Angeli, Milano. 
Scientific Research Publishing (SCIRP) is one of the largest Open Access journal publishers. It is currently publishing more than 200 open access, online, peer-reviewed journals covering a wide range of academic disciplines. SCIRP serves the worldwide academic communities and contributes to the progress and application of science with its publication.

Other selected journals from SCIRP are listed as below. Submit your manuscript to us via either submit@scirp.org or Online Submission Portal.
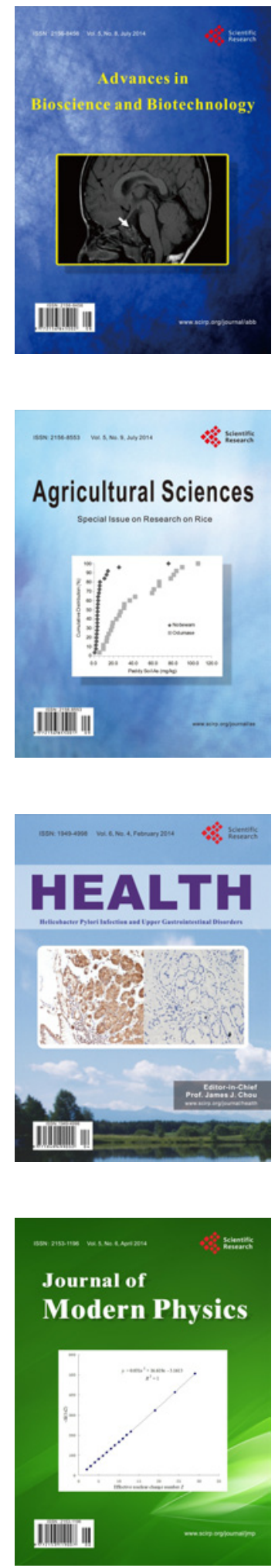
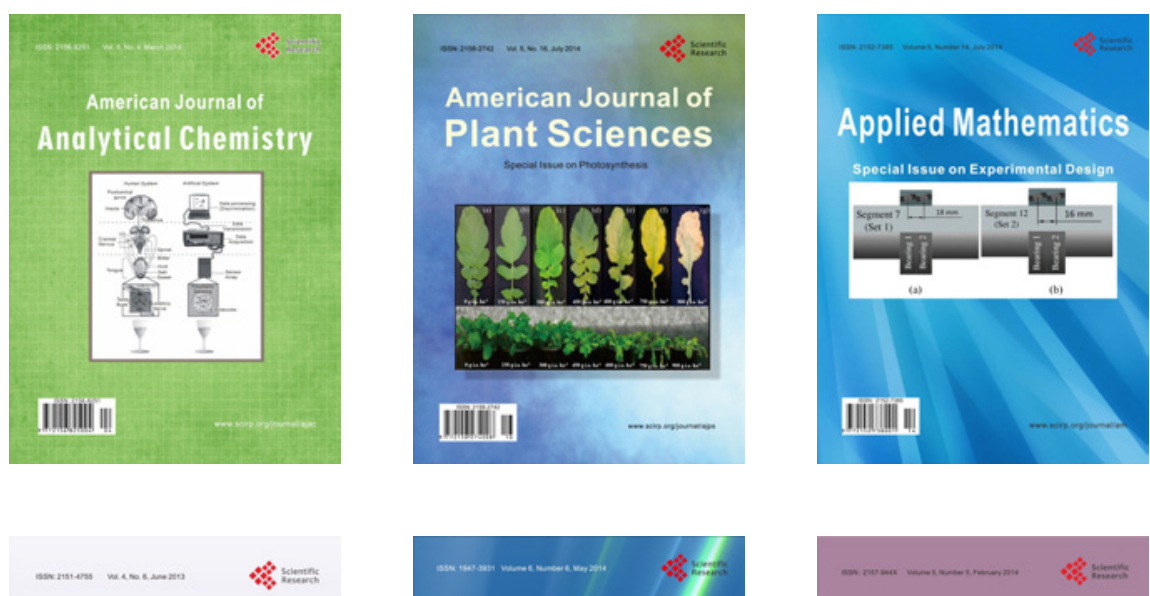

Creative Education
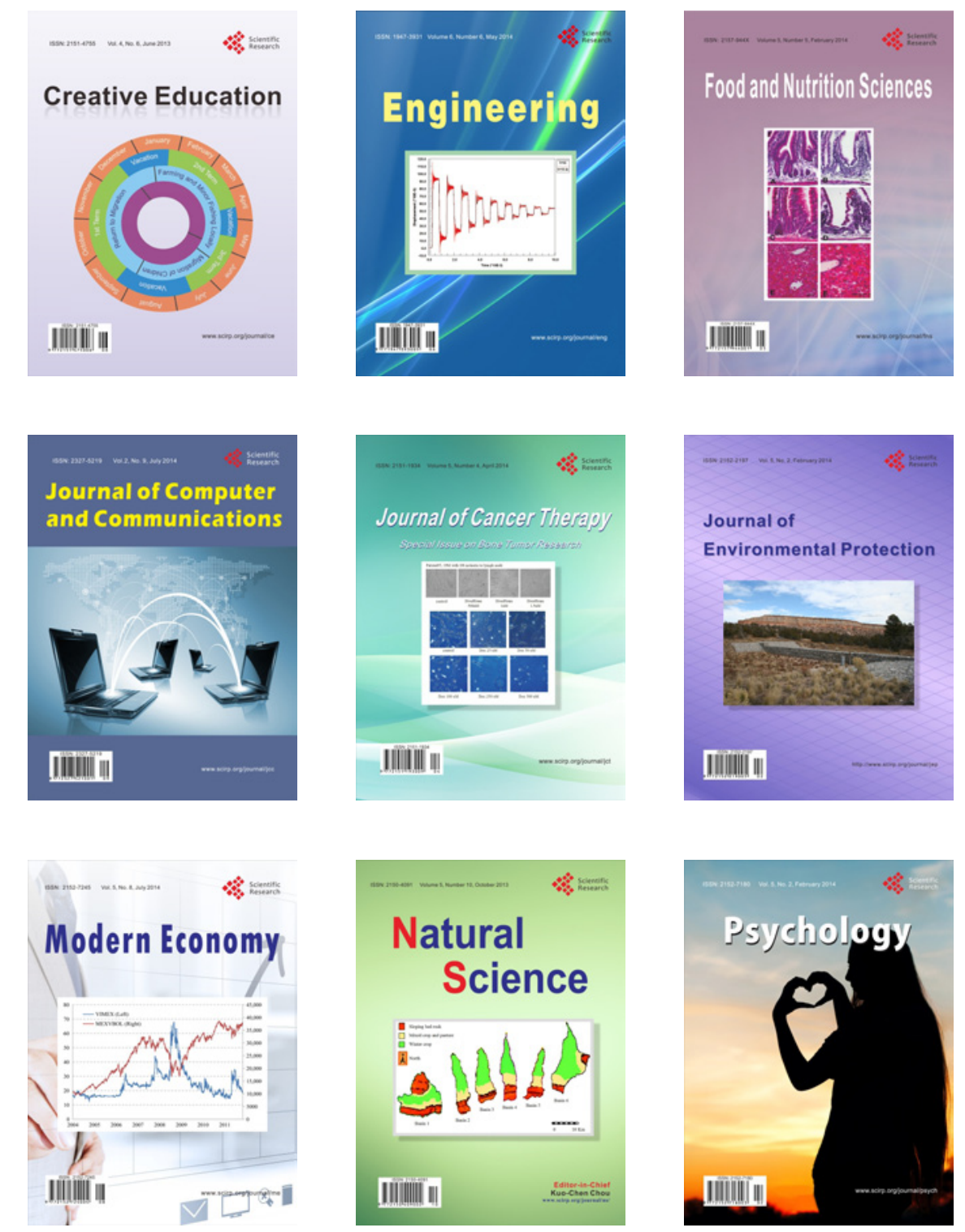